Ann. Zootech., 1980, 29, no h. s., 197-204.

\title{
Intake as dependent on feed
}

\author{
T.A. McCULLOUGH
}

Loughry College of Agriculture and Food Technology, Cookstown, Co. Tyrone, N. Ireland (UK)

\begin{abstract}
A survey of the literature concerned with all-roughage diets indicates that pelleting causes an increase in voluntary feed intake and this is particularly the case with long roughages of low digestibility. Pelleting is likely to have a relatively small effect on the intake of low-protein roughages. Silage of high dry matter will have a greater intake than silage of a low dry matter.

With diets fed to fattening bullocks consisting of silage supplemented with increasing levels of concentrates, rolled barley or died grass the dry matter intake of the basal silage ration decreased but the overall intake of dry matter increased. There did not appear to be large differences in dry matter intake either in the basal silage diet or in the overall diet between the different supplements in the same experiment. One study indicated that long hay as a supplement to silage decreased silage dry matter intake and total dry matter intake to a greater extent than dried grass fed at similar levels.

Silage dry matter intake decreased with decreasing digestibility. The intake of silage of high digestibility was reduced to a greater extent than silage of low digestibility when supplemented with rolled barley.

Hay in the long form when supplemented with increasing levels of either concentrates or dried grass resulted in a decrease of hay dry matter intake and an increase in total dry matter intake. The intake of dry matter was similar with both supplements.

With diets consisting of concentrates and supplemented with either milled and pelleted dried grass or long hay and fed to young calves the daily dry matter intake decreased and the metabolisable energy increased as the metabolisability of the gross energy increased.
\end{abstract}

\section{Résumé}

\section{Variations de l'ingestion liées à l'aliment}

L'examen de la littérature concernant les rations de fourrages montre que leur broyage et agglomération en «pellet » entraîne une augmentation de leur ingestibilité, particulièrement dans le cas de fourrages à faible digestibilité. Ce traitement a probablement un effet relativement faible sur l'ingestibilité des fourrages pauvres en azote.

Les ensilages à haute teneur en matière sèche sont davantage consommés que les ensilages à faible teneur en matière sèche.

Avec des rations à base d'ensilage pour l'engraissement des bouvillons, lorsqu'on a augmenté le niveau d'apport de concentré, sous forme d'orge aplatie ou graminées déshydratées, la consommation de matière sèche d'ensilage a diminué mais la consommation totale de 
matière sèche a augmenté. Pour une même expérience aucune différence importante n'est apparue dans l'ingestion de matière sèche d'ensilage ou de la ration totale en fonction de la nature de l'aliment complémentaire. Un essai a montré que le foin long comme complément de l'ensilage diminuait davantage la consommation d'ensilage et de matière sèche totale de la ration que les graminées déshydratées apportées en même quantité.

La consommation de matière sèche d'ensilage diminue lorsque la digestibilité décroît. L'ingestion d'ensilage ayant une digestibilité élevée est davantage réduite par un apport d'orge que celle d'un ensilage ayant une faible digestibilité.

Lorsqu'on a apporté en supplément d'un foin long des quantités croissantes d'aliment concentré ou de graminées déshydratées, la consommation de foin a diminué mais la consommation de matière sèche totale a augmenté. Cette consommation totale de matière sèche a été la même avec ces deux compléments. Avec des rations d'aliments concentrés distribuées à de jeunes veaux et associées soit à des graminées déshydratées broyées ou condensées, soit à du foin long lorsque la teneur en énergie métabolisable de la ration augmentait, la quantité de matière sèche ingérée diminuait et celle d'énergie métabolisable ingérée augmentait.

\section{Introduction}

The general effects of grinding and pelleting dehydrated roughages are to increase their acceptability and hence intake to the animal, to reduce their digestibility and to improve their net energy value (reviewed by Minson, 1962 ; MoORe, 1964 ; Greenhalgh and Wainman, 1972). However, the magnitude of these effects varies considerably from one roughage feed to another. Minson (1962) concluded that pelleting the roughage in a diet high in nutritive value had less effect on intake than pelleting the roughage in a diet of low nutritive value. GREENHALGH and WAINMAN (1972) showed that this conclusion applied whether variations in nutritive value were due to roughage quality alone or to differences in roughage to concentrate ratio. However, when the diet contains concentrates, the effect of pelleting the roughage is reduced and may even be negative if the diet contains only $20-30$ per cent roughage. Pelleting is likely to have a relatively small effect on the intake of low-protein roughages.

Many experiments have also shown the voluntary consumption of silage to be lower than that of the same crop fed fresh or after drying and that higher intakes of silage are obtained from wilted rather than from unwilted crops (MOORE et al., 1960 ; HARRIS and RAYMOND, 1963).

It is now proposed to consider in detail mixed diets consisting of roughages fed together with a supplement. In this review only comparisons within experiments are considered due to the wide differences in roughage quality and to consider trends in voluntary feed intake as responses to experimental treatments.

\section{Silage supplementation}

a) Dried grass, rolled barley and concentrates

Eariy work by TAYLER (1970) indicated that dried grass pellets (D value 69) depressed silage (D value 70 ) intake less than an equal amount of rolled barley. Furthermore the total dry matter intake was greatest with the dried grass supple- 
ment. Figure 1 shows the effect of supplementing silage with increasing levels of dried grass and rolled barley on intake. Points joined by lines are from similar experiments. Silage dry matter intake declined with small differences between supplements. There was an increase in the total dry matter intake with both supplements with increasing levels of supplement (Figure 2). Regression analysis of results by MCCullough (unpublished) showed that the silage dry matter intake by steers of liveweight $364 \mathrm{~kg}$ was related to the level of supplement by the following significantly $(\mathrm{P}<0.01)$ linear equation :

$$
y_{1}=5.43-0.209 x \quad r=0.486
$$

It was also shown that total daily dry matter intake was related to level of supplement by the following significantly $(P<0.001)$ linear equation:

$$
y_{\varepsilon}=5.43+0.649 x \quad r=0.864
$$

where $y_{1}=$ silage dry matter intake $(\mathrm{kg} / \mathrm{d}), y_{2}=$ total dry matter intake $(\mathrm{kg} / \mathrm{d})$ and $x=$ level of dried grass or rolled barley supplement $(\mathrm{kg} / \mathrm{d})$.

An increase in total dry matter intake of about $0.48 \mathrm{~kg} / \mathrm{d}$ for each $\mathrm{kg}$ supplement was shown by LEAver (1973) when a silage diet was supplemented with concentrates and fed to young growing heifers (initial liveweight $93 \mathrm{~kg}$ ).

McIlmoyle and Murdoch (1977) also showed an increase in total dry matter intake and in digestible energy intake when silage was supplemented with increasing levels of either dried grass or concentrates. The dried grass was, however, perhaps less effective in increasing the intake of digestible energy than concentrates.

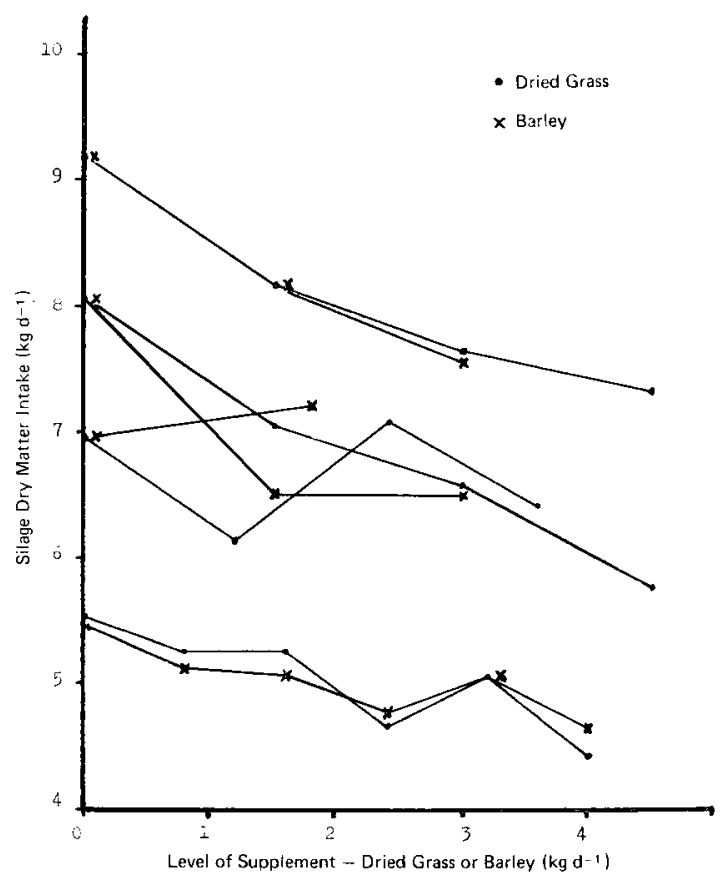

Fig. 1. - Effect on dry matter intake of various levels of dried grass and barley supplements iu silage based diets. 


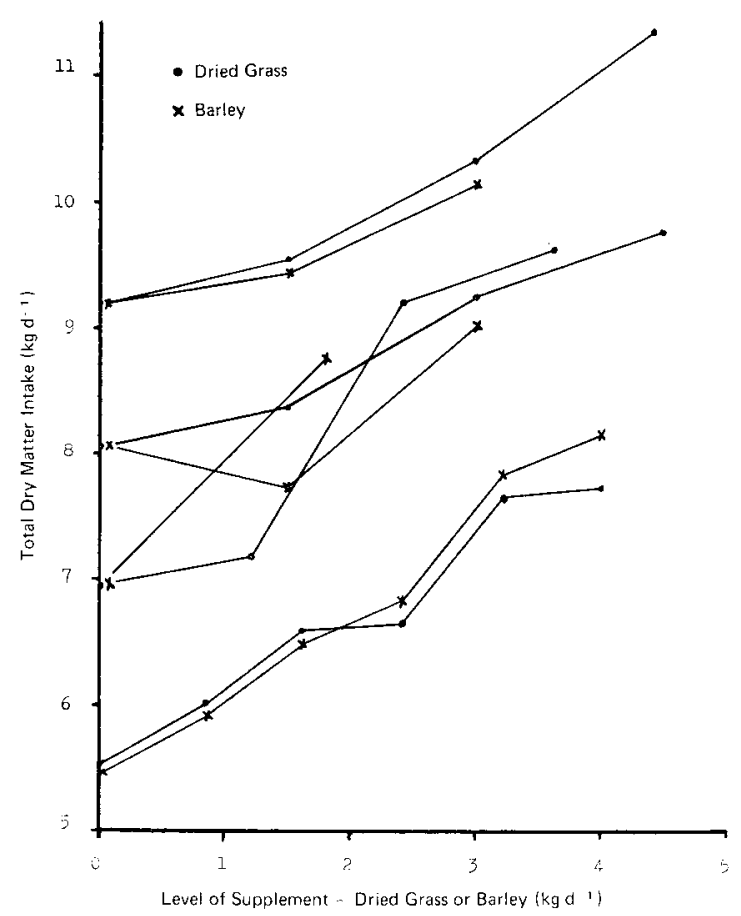

FIG. 2. - Effect on total dry matter intake of various levels of dried grass and barley supplements in silage based diets.

The effect of dried grass or concentrates as a supplement for silage is further confirmed when both were fed as supplements in various conbinations. MCCuLLOUGH (unpublished) showed, over a range of supplements from 100 per cent pelleted dried grass to 100 per cent rolled barley and fed to fattening bullocks at two levels, that silage dry matter and total dry matter intake were not significantly affected. MCILmoYle and MURDQCH (1977) also showed that the ratio of dried grass to concentrate over a similar range did not affect dry matter intake or digestible energy intake. Thus it would appear that there is no optimum ratio to include dried grass and concentrates in a supplement for silage in terms of dry matter intake.

\section{b) Dried grass and hay}

There appears to be a limited amount of information on the response of feeding increasing levels of hay as a supplement to silage. In a study carried out by McCullough (unpublished) increasing levels of either long hay or dried grass were used as a supplement to silage and fed to bullocks ( $360 \mathrm{~kg}$ liveweight). The silage dry matter intake decreased to a greater extent with the hay supplement than with the dried grass supplement. Thus total intake was higher when dried grass was fed. The silage dry matter was related to the level of supplement by the following significantly $(\mathrm{P}<0.01)$ linear equations : 


$$
\begin{aligned}
& y_{1}=6.23-0.10 x_{1} \\
& y_{2}=6.23-0.25 x_{2}
\end{aligned} \quad \mathrm{R}^{2}=0.294
$$

where $y_{1}=$ silage dry matter intake with dried grass supplement $(\mathrm{kg} / \mathrm{d})$

$x_{1}=$ level of dried grass supplement $(\mathrm{kg} / \mathrm{d})$

$y_{2}=$ silage dry matter intake with hay supplement $(\mathrm{kg} / \mathrm{d})$

$x_{2}=$ level of hay supplement $(\mathrm{kg} / \mathrm{d})$.

It was also shown that the total daily dry matter intake was related to the level of supplement by the following significantly $(\mathrm{P}<0.001)$ linear equations:

$$
\begin{aligned}
& y_{3}=6.23+0.78 x_{1} \\
& y_{4}=6.23+0.57 x_{3}
\end{aligned} \quad \mathrm{R}^{2}=0.736
$$

where $y_{3}=$ total dry matter intake with dried grass supplement $(\mathrm{kg} / \mathrm{d})$

$y_{4}=$ total dry matter intake with hay supplement $(\mathrm{kg} / \mathrm{d})$

$x_{1}$ and $x_{2}$ as above.

\section{c) Silage}

In a recent report DAY et al., (1978) described the effect of supplementing grass silage with clover silage on feed intake. Silage dry matter intake was significantly $(\mathrm{P}<0.001)$ lower for animals receiving grass silage alone than those receiving supplements. There was also a significant $(\mathrm{P}<0.01)$ increase in the total dry matter intake as a result of increasing the proportion of clover silage. There was however, no clear indication that the total digestible organic matter was increased with increasing levels of clover silage.

\section{Basal silage diet}

\section{a) Silage quality and supplementation with barley}

Studies by McIlmoyle (personal communication) have shown, as expected, that silage dry matter intake by growing cattle $(300-400 \mathrm{~kg})$ decreased as silage quality decreased. Quality was determined by the interval of cut, this being either 6, 9, or 12 weeks. However, the silage dry matter intake of the high quality silage was reduced to a greater extent by the supplementation with barley than with low quality silage. This is shown in Table 1.

\section{b) Wilting and chop length}

Wilting normally improves silage fermentation and intake is usally higher with low dry matter silage than with high dry matter silage. However the intake may be affected by the level of supplement and the chop length of the material. It has been shown by FORBES and JACKSON (1971) that supplementation depresses intake of high dry matter silage to a greater extent than low dry matter silage. Furthermore it has been shown by MCCullough 1.1. (personal communication) 
TABLE 1

THE EFFECT OF LEVEL OF SUPPLEMENTATION ON DRY MATTER INTAKE OF SILAGES OF DIFFERENT QUALITY $(\mathrm{kg} / \mathrm{d})$

\begin{tabular}{|c|c|c|c|c|c|}
\hline \multirow{2}{*}{$\begin{array}{l}\text { Interval of } \\
\text { cut (weeks) }\end{array}$} & \multirow{2}{*}{$\begin{array}{c}\mathrm{D} \\
\text { value }\end{array}$} & \multicolumn{4}{|c|}{ Level of barley supplementation $(\mathrm{kg} / \mathrm{d}$} \\
\hline & & o & 1 & 2 & 3 \\
\hline 6 & 68 & 5.61 & 4.78 & 4.54 & 4.00 \\
\hline 9 & 65 & 5.10 & 4.72 & 4.77 & 4.20 \\
\hline 12 & 61 & 4.99 & 4.89 & 4.84 & 4.24 \\
\hline
\end{tabular}

that with short chop length $(19 \mathrm{~mm})$ daily silage dry matter intake is increased with increasing level of dry matter. With longer chop length $(70 \mathrm{~mm})$ this does not necessarily occur, there being no clear differences in intake between silages of different dry matters.

\section{Hay supplementation}

\section{Dried grass and concentrates}

In an experiment described by McCullough (1976) steers with a mean liveweight of $168 \mathrm{~kg}$ were fed hay ad libitum and supplemented with increasing levels of either dried grass or concentrates. There were no significant differences in hay or total dry matter intakes between supplements. The hay dry matter intake decreased with increasing level of supplement according to the significantly $(\mathbf{P}<0.001)$ linear relationship :

$$
y_{1}=4.21-0.25 x \quad r=0.68
$$

It was also shown that total daily dry matter intake increased with increasing level of supplement as described by the significantly $(P<0.001)$ linear equation :

$$
y_{2}=4.21+0.60 x \quad r=0.91
$$

Where $y_{1}=$ hay dry matter intake $(\mathrm{kg} / \mathrm{d}), y_{2}=$ total dry matter intake $(\mathrm{kg} / \mathrm{d})$ and $x=$ level of dried grass or concentrate supplement $(\mathrm{kg} / \mathrm{d})$.

This effect of dried grass or concentrates as a supplement for hay is further confirmed when both are fed as supplements in various combinations. MCCuLLOUGH (unpublished) showed over a range of supplements from 100 per cent pelleted dried grass to 100 per cent concentrates and fed at two levels, that hay dry matter intake and total dry matter intake was not significantly affected. There were no interactions in these parameters between ratio of dried grass in the supplement and in the level of the supplement.

\section{Concentrate supplementation}

MCCullough (1974) and McCullough (unpublished) carried out a number of experiments designed to study the effect of replacing an early weaning concentrate ration with increasing proportions of milled and pelleted dried grass or 
long hay on the voluntary feed intake of calves from $50 \mathrm{~kg}$ to $100 \mathrm{~kg}$ liveweight. The effect of the metabolisability (q) of the overall diet i.e. ratio of metabolisable energy to gross energy, on voluntary feed intake, is described by the linear equations given in Table 2 .

\section{TABLE 2}

RELATIONSHIP BETWEEN THE VOLUNTARY INTAKE OF FOOD DRY MATTER ( $\mathrm{I}-\mathrm{g} / \mathrm{kg} \mathrm{w}^{0.75}$ ) AND THE METABOLISABILITY OF THE GROSS ENERGY (q)

\begin{tabular}{llccc}
\hline $\begin{array}{l}\text { Supplement of } \\
\text { concentrate }\end{array}$ & Relationship & $r$ & $\begin{array}{l}\text { Level of } \\
\text { significance }\end{array}$ & Reference \\
\hline Dried grass & $I=125.04-0.617 \mathrm{q}$ & 0.73 & $\star \star$ & McCULLOUGH \\
(1974) \\
Dried grass & $I=106.4-0.452 \mathrm{q}$ & 0.18 & $\mathrm{NS}$ & $\begin{array}{c}\text { McCULLOUGH } \\
\text { (unpublished) } \\
\text { Hay }\end{array}$ \\
& $I=81.95-0.422 \mathrm{q}$ & 0.29 & $\mathrm{NS}$ & $\begin{array}{c}\text { McCuLLOUGH } \\
\text { (unpublished) }\end{array}$ \\
\hline
\end{tabular}

Although a wide variation in intake is indicated there would appear to be a decrease in dry matter intake with an increase in the metabolisability of the overall diet. The depressed intake of the hay supplemented diets may possibly be due to the supplementation with long hay in comparison with the pelleted dried grass supplement of the other two experiments.

The effect of the metabolisability (q) of the overall diet on the voluntary intake of metabolisable energy is described by the linear equations given in Table 3.

TABLE 3

RELATIONSHIP BETWEEN THE VOLUNTARY INTAKE OF METABOLISABLE ENERGY $(I-\mathrm{kJ} / \mathrm{kg}$ WO.75) AND THE METABOLISABILITY OF GROSS ENERGY (q)

\begin{tabular}{|c|c|c|c|c|}
\hline $\begin{array}{l}\text { Supplement to } \\
\text { concentrate }\end{array}$ & Relationship & $r$ & $\begin{array}{l}\text { Level of } \\
\text { significance }\end{array}$ & Reference \\
\hline Dried grass & $I=335.4+10.65 q$ & 0.84 & $\star \star *$ & $\begin{array}{c}\text { MCCULLOUGH } \\
(1974)\end{array}$ \\
\hline Dried grass & $I=120.4+12.55 q$ & 0.52 & $\star * *$ & $\begin{array}{l}\text { MCCULLOUGH } \\
\text { (unpublished) }\end{array}$ \\
\hline Hay & $I=299.0+5.49 q$ & 0.33 & * & $"$ \\
\hline
\end{tabular}

These equations tended to give an improved estimate of intake and indicated an increase in intake with an increase in the metabolisability of the diet. Again the intake on the hay supplemented diet was lower than with the dried grass supplemented diets. 


\section{References*}

Day N., Harkness R.D., Harrison D.M., 1978. A note on red clover silage for cattle finishing. Anim. Prod., 26, 97-100.

Drennan M.J., Lawlor M.J., 1976. Evaluation of pelleted dried grass as a supplement to grass silage for fattening steers. Anim. Prod., 22, 97-103. $(2,3)$

FORBES T.J., JACKSON N., 1971. A study of the utilisation of silages of different dry matter content by young beef cattle with or without supplementary barley. J. Brit. Grassld Soc., 26, 257-264.

GREenhalgh J.F.D., Wainman F.W., 1972. The nutritive value of processed roughages for fattening cattle and sheep. Proc. Br. Soc. Anim. Prod., 1972, pp. 61-72.

HarRis C.E., Raymond W.F., 1963. The effect of ensilage on crop digestibility. $J . B r$. Grassld Soc., 18, 204-212.

I.EAVER J.D., 1973. Rearing of dairy cattle. 4. Effect of concentrate supplementation on the liveweight gain and feed intake of calves offered roughages ad libitum. Anim. Prod., 17, 43-52.

Minson D.J., 1962. The effect of pelleting and wafering on the feeding value of roughages a review. J. Br. Grassld. Soc., 18, 39-44.

Moore L.A., 1964. Symposium on forage utilisation : nutritive value of forage as affected by physical form. Part. I. General principles involved with ruminants and effect of feeding pelleted or wafered forage to dairy cattle. J. Anim. Sci., 23, 230-238.

MoORE L.A., ThOMas J.W., SyKeS J.F., 1960. The acceptability of grass/legume silage by dairy cows. Proc. 8th Int. Grassld Congr., Reading, pp. 701-704.

McCullough T.A., 1972. The effect on fattening steers of supplementing silage with dried grass or rolled barley. J. Brit. Grassld Soc., 27, 115-118. (2, 3).

McCullough T.A., 1972-1978. Unpublished data. $(2,3)$

MCCullovgh T.A., 1974. The effect of different proportions of dried grass and concentrates in the diet on voluntary intake and performance of calves. Anim. Prod., $18,49-58$.

MCCullough T.A., 1976. The effect on young beef cattle of supplementing hay with dried grass or concentrates. J. Brit. Grass/d Soc., 31, 105-109.

McIlmoyle W.A., Murdoch J.C., 1977. The effect of dried grass and cereal-based concentrate on the voluntary intake of unwilted grass silage. Anim. Prod., 24, 227-235.

TAYLer J.C., 1970. Dried forages and beef production. J. Brit. Grassld Soc., 25, 180-190.

$\left(^{*}\right)$ The numbers in parentheses refer to Figures 1 and 2 and indicate that the reference has been used as a source of information for the figures listed. 


\section{Discussion}

\section{Chair : Sir Kenneth Blaxter ( $U K)$}

Sir Kenneth Blaxter $(U K)$. - I would like to start the discussion by asking Dr. Forbes about a statement he made when he was saying that, from the practical point of view, there is very little we can do within the area in which the non-physical regulation takes place because any increase in food intake, at that time, will have met requirements and all that will happen will be a deposition of fat. I wonder if this is true. I do not think that our animals are up to limits with regard to the time rates of protein deposition. Appetite, even in this non-physical regulation area, comes into operation very much earlier.

J.M. Forbes $(U K)$, - I think it is a simplification in the same sense you can simplify talking about the control of intake in saying, "That's physical and that's metabolic". You can similarly simplify talking about the relationship between food intake, whether it is restricted by the farmer or whether the animal controls it, and protein and fat deposition. It is clear that in the growing animal, just above maintenance, it is depositing mostly protein and the faster and faster above that it grows, the more and more fat it is depositing. Therefore, there is an infinite variation between a lot of protein and not much fat, right through to a lot of fat and not much protein. To say that protein deposition stops here is wrong.

Sir Kenneth BLAXTER. - I take that point, but what we are concerned with is really in the area where increase in dietary concentration tends to cause depression in dry matter intake. Would there be any benefit in taking the cow, or the cattle beast, up further. In other words, what is the shape of the food intake/protein deposition curve, and is it worth trying for that extra little bit? We want to know where to put effort ; do we put effort in there? Would anybody like to comment on this?

\section{J.M. Forbes. - My answer would be that I don't know.}

Sir Kenneth Blaxter. - Does anybody else know ? Is it worthwhile trying to increase the appetite in animals which are getting highly concentrated diets, and are already gaining $1.4,1.5$ or $1.6 \mathrm{~kg}$ per day ? Should we try for even more ?

C. Beranger (France). - I think it depends on the kind of animals. For example, with Charolais, especially with the Limousin breed, we have low appetite and high protein deposition. In this case it would be interesting to increase appetite because although you would certainly increase fat, you would also increase protein and so on. Therefore, in certain circumstances, with animals which are able to use a high concentrated diet very efficiently because of the high protein deposition potential, it would be more efficient to increase appetite.

K. RoHR (Federal Republic of Germany). - In answering this question we must take the feeding system into account. For instance, in our country, having a fattening period immediately after the rearing period, and going straight through to fatten to $500 \mathrm{~kg}$ with these Friesian type bulls, when we tried to increase the concentrate portion to a very high degree - let's say increasing the average daily gain in this period from about $1050 \mathrm{~g}$ to $1150 \mathrm{~g}$ - there was no increase in protein, just an increase in fat.

G. AlLERMAN $(U K)$. - Take the fairly well recorded information about intensive cereal diets to Friesian steers. There is a period effect. On ad libitum feeding of a high energy diet, where almost certainly intake is being controlled metabolically, the rate of gain declines with time. We appear to be in a situation where the animal is choosing to decline the rate of gain. Certainly we are getting high fat gains in these animals. I wonder whether we should re-examine our approach to the proteins - and even the amino acid make up. This is going back to our discussion of this morning, and whether the composition of protein gain is well matched to microbial protein ; it is a point which did not come out. Yesterday I referred to the fact that the Meat and Livestock Commission, with their dried grass and barley diets 
with bulls, achieved far higher rates of gain ; well beyond the 15 per cent increase which is normally recorded between steers and bulls. But it was a specific diet, fed ad libitum, which was pelleted and which seemed to get round some of the constraints of the conventional rolled barley and protein supplement type of diet, which we call intensive cereal in the UK.

J.H.B. RoY $(U K)$. - There is one point which ought to be mentioned. In calves of between 7 and 12 weeks of age, by increasing the concentration of dry matter milk substitute diets, one can get up to growth rates of $1.6 \mathrm{~kg}$ per day. However, one certainly stresses the animals in that these animals are much more susceptible to respiratory infections. I think that is a thing which ought to be kept in mind when one is thinking of maximising protein and fat deposition.

H. Refsgand Andersen (Denmark). - In Denmark we feed at a very high feeding level because we produce bulls which are slaughtered at a low weight, and when we slaughter at a low weight, we have to feed at a high level because of the carcase quality. The animal cannot be too fat at this low weight. Therefore, we have to feed at a high feeding level.

Sir Kenneth Blaxter. - Therefore we can say that even when there is no evidence of physical regulation - that is to say, in the so-called region of maximal metabolic regulation - that there is still advantage in a number of circumstances in increasing voluntary food intake. How do we do it? Does anybody have any ideas ?

J.M. Forbes. - One thing that I did not deal with was positive factors which encourage feeding. Unless you go in for anaesthetics and drugs, there are techniques which attract the animals to the food and make it eat a few minutes earlier than it would have done. One example, of course, is offering the animal fresh food. This will very of ten induce a very large meal. It is a thing which dairy farmers are learning to do ; to feed their cows 6 times a day instead of only at milking. Whether the same thing has been tried with beef cattle, and whether it works, I don't know.

Sir Kenneth Blaxter. - How effective are these techniques in the long term ? You can get short term responses, in terms of intake, by disturbance factors and so on.

\section{J.M. Forbes. - I do not think they have been looked at in critical experiments.}

A. Neimans-Sф $\varnothing$ Rensen (Denmark). - With regard to the last question, we have been using the "cafeteria system" not for beef" animals but for dairy cows. We put five different feeds before the cows for them to choose - sugar beet, maize silage, molasses, concentrate mixture and ensiled brewers' grain. That was for one group of cows ; the others got the same ingredients, but in a complete feed. The cows in the cafeteria system were eating up to $50 \mathrm{~kg}$ sugar beet a day. They did this over a long period; it was a group experiment over reveral months. Normally a cow would te in trouble if she ate so much, but we did not experience any trouble.

Sir Kenneth Blaxter. - So we have a cafeteria system which, I might add, has been extremely successful in rats. With the rat, the cafeteria system feeds them on a chocolate covered caramel bar (called a Mars Bar in the UK) and sweets and so on. This enables the rats to take in so much that they become grossly obere. It is a technique that has been used by Miller to study experimental obesity in the rat.

So we have cafeteria feeding, which is successful to some extent. In effect it says that the cow knows best what she would like, and will eat the most of it. But do all cows do the same? I found, thirty odd years ago, that some cows would eat very large amounts of onz thing, on a cafetcria system, and o:hers would eat different things.

A. Nemann-Sørensen. - I do not think I can give any reliable figures, but we can find out and we are continuing these types of experiments However, they were all certainly eating a great deal.

H.J. OsLaGe (Federal Republic of Germany). - Your statement, Sir Kenneth, would mean that the feed intake would limit meeting the nutritive requirement of beef cattle. I would hesitate to agree with this statement. It is certainly true for dairy cows, but with beef cattle it is true only in certain cases. It may appear to be valuable to increase the feed intake for certain periods or under certain conditions for beef cattle, but I think we have to recognise the whole fattening period ; for instance, we have these compensatory factors within 
the period if we have different feeding systems. My opinion would be that, in general, the feed intake is not a limiting factor in meeting the nutritive requirements of beef cattle. The feed intake of beef cattle is, say, 2.0 to 2.5 times maintenance requirement, but the respective figure for dairy cows is 4.0 or 4.5 .

G. Alderman, - I would like to quote some of the experience of Reading University with their bull beef unit on maize silage. This was available, ad libitum, all day long, fed on the floor to bulls in pens. With an uncontrolled experiment they found that if they used a simple plough — just going down and turning the maize silage over - they could encourage a greater daily dry matter intake, and increase the rate of gain. That is all they had to do - - just turn the maize over and get the fresh smell of it, and the animals would come and eat. In terms of your model, it suggests that the hypothalamus integrated all responses in parallel and initiated eating.

J.M. Forbes. - That is the point I make in my paper - about the positive "feed forward", as the psychologists call it.

Sir Kenneth Blaxter. - Are there any other positive factors, as with the sheep and the light effect?

J.M. Forbes, - Yes, but I think that can be explained entirely as due to the extra growth that we get in long day length. If you pair-feed lambs, some in 16 hours of light and some in 8 hours of light, the long day length onzs grow more but they are thinner. There is still an effect, even in the absence of any possibility of eating more. In those circumstances the food intake rises in long day length in response to increased energy deposition rather than in response to a direct effect on food intake. However, it is clear that if the animal can see the trough for 16 hours a day, instead of 8 hours a day, then it may be encouraged to eat more - I would not like to separate this. eat?

Sir Kenneth Blaxter. - Do you think that this is due to being able to see to

J.M. Forbes. - No, because we have measured intakes during the light hours and the dark hours of our 2 day lengths, and they certainly ate plenty of food during the night - not as much per hour as during the day, but quite a lot.

Sir Kenneth Blaxter. - - I recall reading in one of your papers a quote from the Meat and Livestock Commission's barley beef siutuation, with higher gains in summer, which I believe you attribute to light.

J.M. Forbes. - That seems to be the most likely thing. Although I did not mention it in that paper, Brian Kilkenny, who actually sorted out this data from MLC records, found there were a few farms which kept the lights on all night, and the weight gains in those beef-lots still seemed to show the same fluctuation. I just don't know. I very much suspect that if the light is on all the time, $i_{\hat{\imath}}$ is no better than a short day lengih ; I think long days are better than continuous light.

C. V. Boucque (Belgium). - Concerning the effect of feeding root crops to beef cattle ; it is generally known that feeding fodder beets, as in Denmark, increases intake. We tried to do the same with fresh potatoes, in supplementation to a maize silage diet. We had to repeat it three times. For the first two series we observed that, during the first six months - starting at $260 \mathrm{~kg}$ liveweight - there was a supplementary intake of dry matter from the three components. But afterwards, for the last three months, some animals even refused fresh potatces. Does anyone have an explanation for that?

G. Alderman. - It leads on to another point I wanted to make, if I may. I think you said you were feeding fresh potatoes on top of maize silage.

C. V. Boucoue. - The control was only maize silage, ad libitum, and a limited anount of concentrates.

G. Alderman. - So we have a starchy basal diet, with a starchy additive to it. I just wanted to put this in context with current practice in the UK where compound feeds - as they are commonly manufactured and supplied to farmers - have starch contents well below that which you will find in cereals, so that the substitution rates that we find for cereals would not be true for the considerable majority of the purchased compound feed 
and protein supplements available in the UK. I would think this is probably true for a number of continental countries as well. In other words, there is so much in the way of by-products and hemicellulose in these feeds that at the practical level we need information on substitution rates for manufactured proprietary feeds. It is true that cereals are used as a supplement, but a proportion of our cattle are fed on these other materials where you do not get this interaction, particularly with silage with a high lactic acid content. If you add starchy foods to that, then you get an interaction which appears to be mediated through lactic acid production in the rumen.

C. V. Boucque. - But why was there a difference between the first six months and the last three months? The concentrate was not on a cereal basis, it was at least 60 per cent sugar beet pulp in the concentrate.

G. Alderman. - Thank you, that is a very important point. But sugar beet pulp has a high sugar content from the molasses.

C. V. Boucrue. - It was not molasses. The sugar content was only 6 per cent in total, on a dry matter basis.

Sir Kenneth BLAXTER. - I think we should come to this question, which was touched on briefly by $\mathrm{Mr}$. Alderman and was certainly discussed very fully by Dr. McCullough, and that is the matter of substitution. It has been suggested that we look at every feed in every possible way and look at it rather empirically perhaps. I think there may be sufficient information available now to bring the whole of this substitution work together.

We will take the first simple hypothesis to start with. I was going through the points that Dr. McCullough made in his paper, and I cannot see a single one that does not fit to the general hypothesis that foods substitute one for another in proportion to their maximal voluntary intakes, in the range of physical regulations as direct proportionality. If you get into the range of metabolic regulation then they track, in terms of substitution, the general broad descriptive curve relating apparent digestibility to voluntary intake. This is the suggestion - any comments ?

K.RoHR. -- I think this discussion on substitution rates brings us back to the question of frequency of feeding. When we have a higher frequency of feeding of concentrates - let's say giving the concentrate portion in 4 or 6 meals a day, as compared to twice-daily feeding - we do not have this drop in rumen $\mathrm{pH}$ and consequently we don't have these high substitution rates. There is quite a lot of German evidence of this.

R. JARRIGE (France). - Just a comment on the general scheme of Baumgardt relating dry matter intake to digestibility. I think that this general curve from Baumgardt was derived from a mixture of rations including, more or less, concentrates. However, it does not apply to diets based only on forage and mainly on fresh herbage. If you feed the animal with fresh herbage - for example, ryegrass or fresh lucerne - you have an almost constant increase of the dry matter intake with the digestibility. Everything can be explained by the rate of digestion of the cell wall components inside the rumen. However, with concentrates I agree entirely with the comments concerning the substitution rate in relationship with voluntary dry matter intake of forage. We have included these substitution rates in our fill unit system, which will be presented by Dr. Béranger.

J.M. Forbes. - May I come back to that, as it was partly directed towards me. My second slide, which was similar to the Baumgardt curve but more general, was making the point that there is not a curve, but a whole family and, under some circumstances, you will get a continuation of the physical part of the curve to very high levels of digestibility, particularly with high yielding cows and particularly with a food which is bulky, such as fresh grass. Yes, I think that, under some circumstances, you would not expect to reach the point at which the curve begins to turn out.

R. JARRIGE. - You should have included a palatability factor. This is quite important with silage.

J.M. FORBES. - The question is, how to model this mathematically ?

Sir Kenneth Blaxter. - If we could know what a cow really likes when she tastes things, it would be very nice. Voluntary food intake, which we can measure, is reasonable and we have to infer palatability; it becomes a circular reasoning if we are not very careful. 